\title{
SLC46A1 wt Allele
}

National Cancer Institute

\section{Source}

National Cancer Institute. SLC46A1 wt Allele. NCI Thesaurus. Code C107467.

Human SLC46A1 wild-type allele is located in the vicinity of $17 q 11.2$ and is approximately $13 \mathrm{~kb}$ in length. This allele, which encodes proton-coupled folate transporter protein, is involved in transport of both folate and antifolate across the plasma membrane, and heme transport in duodenal enterocytes. Mutations in this gene are associated with hereditary folate malabsorption. 